\title{
The Corregidores of the Colca Valley, Peru: Imperial Administration in an Andean Region
}

\author{
Noble David Cook
}

Florida International University

The corregidor de los indios was introduced into the Viceroyalty of Peru by Governor García de Castro in 1565. The institution was designed to limit the power of the encomendero elite and to improve administration and justice in the Andean countryside. Here we examine the impact of the reforms at the local level, the corregimiento of Los Collaguas in the Colca Valley, located between Cuzco and Arequipa. Althought the Crown was largely successful in weakening the encomienda, possibility of graft corrupted all but a handful of corregidores. The residencia did check some of those abuses.

KEYwordS: Administrative reform, corregimiento, encomienda, corruption, Colca Valley, Peru.

El gobernador García de Castro fue quien introdujo (1565) el corregidor de los indios en el virreinato del Perú. El corregimiento fue establecido para limitar el poder de los encomenderos y mejorar la administración y la justicia en los sitios rurales, y al mismo tiempo incrementar la colección del tributo. En este trabajo examinamos el impacto de las reformas en el corregimiento de los Collaguas situado en el hermoso valle del río Colca entre Arequipa y Cuzco. Aunque la corona fue más exitosa en debilitar la encomienda, la posibilidad de soborno corrompió a la mayoría de los corregidores.

PALABRas Clave: reforma administrativa, corregimiento, encomienda, corrupción, Valle del Colca Perú.

Corregidores quickly replaced the encomenderos as the principal administrators of native Americans in the Andean countryside after their introduction by Governor Garcia de Castro in the 1560s. Although the spiritual realm of daily existence remained under the direction of European priests and friars, the political, economic and social spheres were controlled primarily by corregidores. The monumental study of the corregidores in Peru was conducted by Guillermo Lohmann Villena in the 1950s. Perhaps because of the quality of his research and the thoroughness of the analysis little more has been done on the subject. ${ }^{1}$ The purpose of this brief

1 Lohmann Villena, Guillermo: El corregidor de indios en el Perú bajo los Austrias, Ediciones Cultura Hispánica, Madrid, 1957; véase también su estudio sobre el arbitrista "Bartolomé de Góngora y su tratado, El corregidor sagaz", Revista de Historia de América 55/56, Madrid, enero/dic. 1963, págs. 139-58. Para la relación entre el encomendero y corregidor véase Keith, Robert G.: "Encomienda, hacienda and corregimiento in Spanish America: A Structural Analysis", Hispanic American Historical Review 51:3, Durham, 1971, págs. 441-46. Hay varios trabajos sobre la etnohistoria enfocando en las unidades de corregimientos, especialmente para el Ecuador, Bolivia y Chile; destacan entre otros los de Ortiz de la Tabla y Ducasse, Javier: "Panorama económico y social del corre- 
article is to explore some of the activities of the corregidores, particularly those associated with economic affairs, that shed new light on the uneasy relationship between colonial bureaucrats and native peoples who were being forcefully integrated into a developing export economy. In particular the perennial issue of corruption will be explored.

The corregidor de los indios as envisioned by García de Castro in 1565 provided a new administrative structure in Andean America; the corregidor was a salaried Crown agent who served at the discretion of his sovereign. He was required to live in the Indian district and along with local kurakas was responsible for collection of tribute and its transport to the nearest treasury office. Unlike the encomendero, he administered local justice in the first instance. The corregidor's tenure was brief, and his income was paid from tribute. Early in 1565, García de Castro introduced the system, but the intellectual precedent had been set in place earlier, when Pedro de la Gasca detailed recommendations for the improvement of the administration of Peru in a letter to Charles V (17 October 1554). He had pressed for the introduction of corregidores, with powers similar to those on the Península for all Andean colonial towns, but cautioned that the officials should not have access to land. La Gasca warned that the Peruvian "landowners are so greedy that they do not keep the rules regarding tributes and kind treatment of the Indians." ${ }^{2}$

Governor Lope García de Castro created in the Colca Valley and the surrounding punalands, the colonial corregimiento or province of Los Collaguas on 3 June 1565. The newly constituted administrative unit was bordered on the east by the new corregimiento of Cana y Canchis, in the northwest by Condesuyos, in the west by Camaná, in the south by Arequipa, in the southeast by Lampa, and in the northeast by Chumbivilcas. The boundaries were imprecise; no thorough land survey

\footnotetext{
gimiento de Quito 1768-1775”, Revista de Indias 36, núms. 145-146, Madrid, julio/dic., 1976, págs. 83-98; y del mismo autor "La población indígena del corregimiento de Riobamba, Ecuador, 1581-1605: la visita y numeración de Pedro de León”, Historiografía y Bibliografía Americanista 25, Sevilla, 1985, págs. 1-69. Véase también Anda Aguirre, Alfonso: Corregidores y servidores públicos de Loja, Banco Central del Ecuador, Quito, 1987; Larraín Barros, Horacio: “Apuntes para un estudio de la población del corregimiento de Otavalo a fines del siglo XVI”, Sarance 4, Otavalo, Ecuador, julio 1977, págs. 6395; Chacón Zhapán, Juan: Historia del corregimiento de Cuenca, 1557-1777, Banco Central del Ecuador, Quito, 1990; y Carrera Colín, Juan: "Apuntes para una investigación etnohistórica de los cacicazgos del corregimiento de Latacunga: siglos XVI y XVII”, Cultura. Revista del Banco Central del Ecuador, 11, Quito, 1981, págs. 129-79.

2 From Panama to Peru: the Conquest of Peru by the Pizarros: the Rebellion of Gonzalo Pizarro and the Pacification by La Gasca, London, 1925, págs. 540-41.
} 
Figura 1. Ubicación del Valle del Colca*

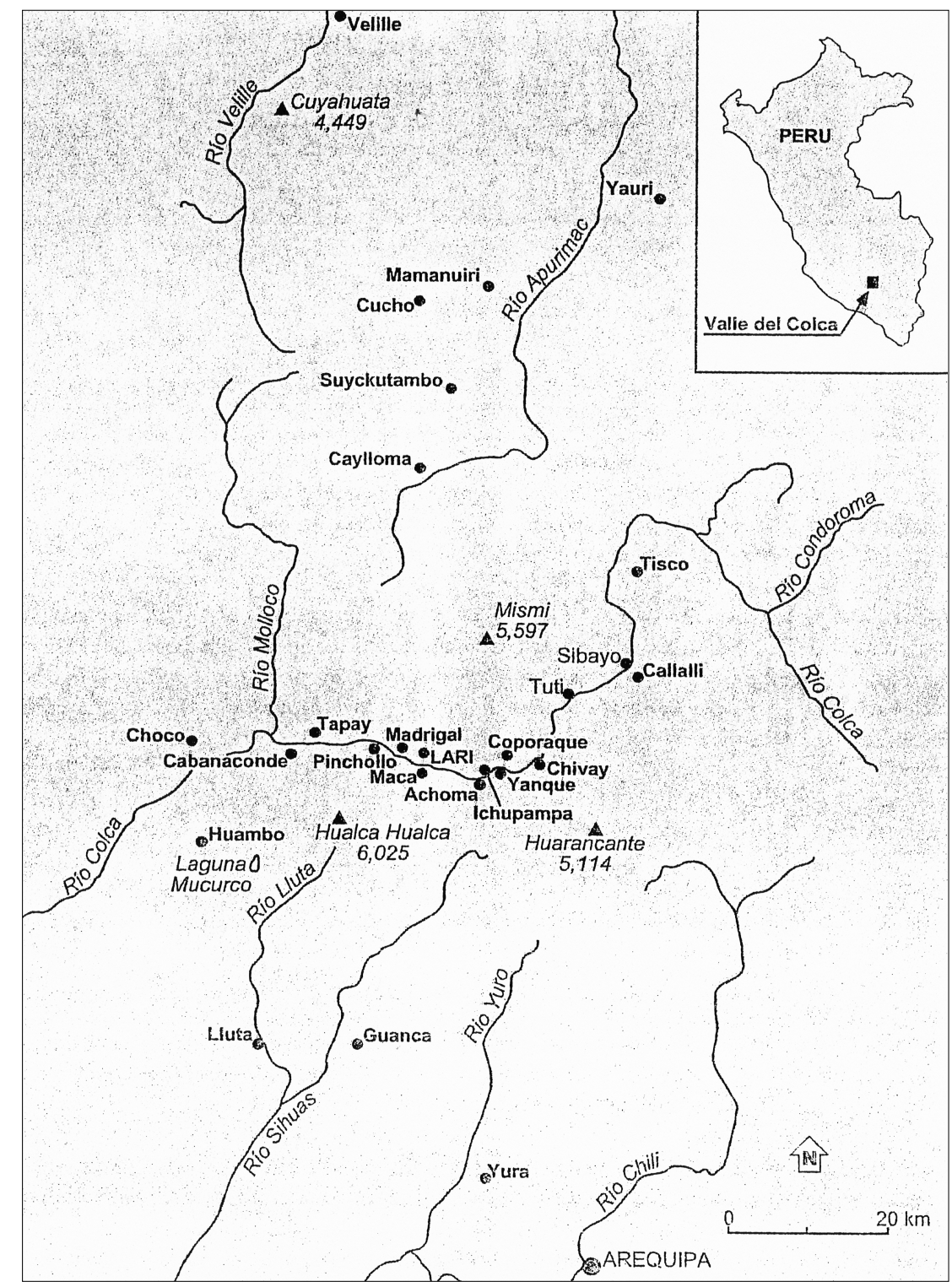

* Robinson, David J. (ed.): Collaguas II, Lari Collaguas. Economía, sociedad y población, 1604-1605, Pontificia Universidad Católica del Perú, Lima, 2003, pág. xxxviii. 
was taken at the time. The vague lines separating the units ran along the peaks of mountains, in stream beds, or in relatively unpopulated stretches of the high puna. In this case, no explanation was given by the governor who established the new system of why the corregimiento was not named after its two principal ethnic entities (the province of the Collaguas and Cabanas, for example). The reason might have been that he had already set up the nearby corregimiento of Cabanas in the jurisdiction of Cuzco and the use of the same name could cause confusion. García de Castro named Juan de la Hoz as first corregidor of the Collaguas, and designated the site of Yanque as the capital of the corregimiento. The shift of the center of authority in the Colca Valley from the village of Coporaque on the north - Cuzco side of the river to Yanque on the south - Arequipa side was made at this time. This move was permanent, lasting to the end of the colonial period. ${ }^{3}$

The number of repartimientos making up a typical corregimiento in Governor García de Castro's plan varied; there could be a handful, or as many as twenty, and even more. The corregimiento could be considered an Indian province, for many often followed earlier Inca or pre-Inca "ethnic" groupings. ${ }^{4}$ In the Colca Valley the new official of the corregimiento de los Collaguas, or province of the Collaguas as it was also known, administered five repartimientos. Thus, when the corregidores de los indios assumed office the direct influence of the encomenderos over the Cabanas, Lari and Collaguas was sharply diminished. The encomenderos still wielded economic power because of their investments, especially their control over land, and the use of tributaries in their households in the city of Arequipa. Yet their overall influence declined as the corregidor became the most important figure in administration of Indian districts. But the corregidor never became a permanent local political force because his term of office was

3 Biblioteca Nacional de Lima (BNL), B 478; Málaga Medina, Alejandro: "Los Collaguas en la historia de Arequipa en el siglo XVI", en Pease, Franklin (comp.): Collaguas I, Pontificia Universidad Católica del Perú, Lima, 1977, págs. 116-18. Véase Robinson, David J. (ed.): Collaguas II, Lari Collaguas. Economía, sociedad y población, 1604-1605, Pontificia Universidad Católica del Perú, Lima, 2003; Denevan, William M.: Cultivated Landscapes of Native Amazonia and the Andes, Oxford University Press, Oxford, 2001; y Treacy, John M.: Las chacras de Coporaque. Andenería y riego en el Valle del Colca, Instituto de Estudios Peruanos, Lima, 1994.

4 BNL, B 478; págs. 101, 118. Véase Cook, Noble David: The People of the Colca Valley: A Population Study, Westview Press, Boulder, Col., 1982; y del mismo autor "Cabanas y Collaguas en la era prehispánica”, en Varón Gabai, Rafael y Flores Espinosa, Javier (comps.): Arqueología, antropología e historia en los Andes. Homenaje a María Rostworowski, Instituto de Estudios Peruanos, Lima, 1997, págs. 379-98. 
strictly limited. Only if the corregidores were able to link themselves to the encomendero elite could they become a significant local political and economic force. The Crown recognized that possibility and attempted to prevent it by making it illegal, at least in theory, for the two groups to unite by marriage alliances.

The term of office for the corregidor de los indios was limited. Juan de la Hoz, the first Colca Valley corregidor was appointed in 1566 and served approximately five years until Lope de Suazo replaced him in 1571. Lope de Suazo acted as the principal official in the corregimiento during the resettlement policy and the general census and tribute assessment ordered by Viceroy Francisco de Toledo. He was followed by Juan de Vergara, who officiated only one year, 1578; Vergara was replaced by José de Villalobos in 1579 who served until Lucas de Cadabal assumed office, serving as corregidor from 1581 to 1583, when Juan de Ulloa Mogollón arrived. Ulloa Mogollón acted as corregidor for seven years, and was responsible for the relación geográfica of the Collaguas. There are many sixteenth century examples of the way the corregimiento system functioned at the local level in the Colca Valley. Once the new official received a letter of appointment from the Crown in Spain, a number of largely ceremonial acts took place before he actually assumed administration of Indian communities in the countryside. For example Captain Gaspar Verdugo, who followed Ulloa Mogollón, presented himself to the viceroy (30 January 1590) in the capital of Lima, with a royal cédula that named him corregidor of the Collaguas, of the "repartimientos of Yanque Collagua, and Lari Collagua of Francisco Hernández de Retamoso, and Lari Collagua of Alonso Picado, and Cabana of Diego Hernández de la Cuba, and Cabana of Hernando de la Torre." The term of office stipulated by the royal order in this instance was just one year, and Captain Verdugo was to receive a salary of 1,200 pesos, which was to be paid from the "caja de la comunidad." According to the order the new corregidor was to have legal jurisdiction over Indians and Spaniards, and anyone else living in the area, and was expected to administer justice fairly, and to especially foster and protect the welfare of the Indians. Captain Verdugo was charged with collection of tribute, and was ordered to make certain that all the Indians were Christians, and that they did not leave their settlements. He was instructed to ensure that the Indians had enough land for their houses and fields, and that they were not mistreated by their kurakas. No new churches or monasteries were to be constructed without approval from authorities in Lima. The corregidor was 
told to enforce various other ordinances and especially to ensure that the natives were protected. Any fines levied by the corregidor were to be remitted to the treasury officials in the city of Lima. After his interview with the viceroy Captain Verdugo traveled to the city of Arequipa where he took the oath of office before cabildo officers (20 March 1590). ${ }^{5}$

The corregimiento system took almost complete control over the natives of the Colca Valley away from the encomenderos. The question of perpetuity of the encomienda was no longer the issue that it had been for the once powerful encomendero was now little more than a pensioner. The administration of Governor García de Castro continued until 1569, and he is known for other important developments. He set into operation the Lima Mint in 1566, and had attempted a general population count and tribute assessment (1565), but this was never completed, although we do have important results for the rich Crown repartimiento of Chucuito in 1567. García de Castro was an active supporter of the Second Lima Church Council of 1567-68, and oversaw the introduction of the first Jesuits into Peru (March 1568). He supported important new naval expeditions to explore the South Pacific Ocean, and tightened defenses against the Chiriguano Indians on the southeastern frontier of the viceroyalty. García de Castro oversaw the organization of the Indian town of El Cercado on the edge of Lima. In 1567 the Audiencia of Chile was established, and the operation of the Royal Audiencia of Quito was competed under his administration. García de Castro's activities throughout the viceroyalty, including those in the Colca Valley, prepared the way for the work of the more famous Viceroy Francisco de Toledo, who replaced him. ${ }^{6}$

One key weakness in the early colonial system, from the viewpoint of the peninsular bureaucrats, was the nature of the indigenous settlement pattern. When the Europeans first reached the Colca Valley, the native Americans were scattered as they were in much of the rest of the southern Andes, in small settlements in the countryside. A Franciscan report of 1585 is quite explicit: "in olden times there were a great number of pueblos of fifty to one hundred Indians because at that time they were not reduced as they are now...." Dozens of hamlets dotted the landscape of the Colca

5 Libros de Cabildo de Arequipa (LCA), 06. Libro 7.

6 Vargas Ugarte, Rubén: Historia general del Perú, vol 2, Editor Carlos Milla Batres, Lima, 1981, págs. 129-75.

7 Quiero dar las gracias al historiador franciscano Antonine Tibesar O.F.M. por la copia de este texto sumamente importante. 
Valley. Most of these were small, some with only a handful of families, or the members of a single ayllu. The idea of forcing the Indians to leave the countryside, and settle in larger communities, where they could be more easily watched and indoctrinated, was discussed early in the conquest of Peru, by Francisco Pizarro, friar Vicente de Valverde, and various religious authorities. More than one royal official was ordered to undertake concentration. Not long after Hernando Pizarro returned from Pachacamac, Francisco Pizarro began a policy of settling Indians. In March of 1534 Almagro wrote the king that "with the villages and communications with the Spaniards the caciques and Indians will come more truly to the knowledge of our Holy Catholic Faith."' Viceroy the Marqués de Cañete in Lima on 23 October 1559 acted to reduce some Indians into towns. Likewise, his successor, the Conde de Nieva wrote (26 December 1562), "I am also intending to bring together the Indians into large pueblos, because they are now scattered through the sierra without having a fixed house, and in this fashion they will have, and can have a public order and be indoctrinated, all this for the service of God and Your Majesty." The viceroy notified the monarch that the licentiate Muñatones advocated the same settlement process. The members of the Second Church Council Meeting in Lima in 1567-68 recommended that the Indians be established in villages as ordered by the king. They suggested that the Indian parish should not be larger than 400 married couples, and if there were more, then the bishop should establish a second parish. But the Spanish were unable to concentrate the population into larger units until they were in a position of strength to enforce such a policy. ${ }^{10}$

Spanish official and jurist Juan de Matienzo outlined his vision of a settlement policy in Gobierno del Perú (1567). Matienzo traced in careful detail the formulation of the new pueblos de indios. He mapped the typical town layout, with its central plaza, the church on one side, and a series of houses for Spaniards and travelers directly opposite. On one of the side blocks there was to be the house of the corregidor, the jail, the residence of the tocuirico (local governing official in the time of the Inca, the equivalent of colonial kuraka). On another block to the side of the plaza the hospital

8 Tibesar O.F.M., Antonine: Franciscan Beginnings in Colonial Peru, Academy of American Franciscan History, Washington, D.C.,1953, págs. 39-40; original en la New York Public Library, Rich Collection, vol. 82 , fol. $71 \mathrm{~b}$.

9 Archivo General de Indias (AGI), Lima, 28A.

10 Vargas Ugarte, Rubén (ed).: Concilios Limenses, 3 vols., Tipografía Peruana, Lima, 1954, vol. 1, págs. 249-50. 
was to be housed, as well as the cabildo building, and a corral for animals and storage. Matienzo believed the ideal size of the new town would be 500 tributaries. If there were 600 or 700 tributaries in a repartimiento, then two towns should be founded, with the population equally divided. Each town block was to have four solares, and the streets were to be wide and straight. Whenever possible, the houses of the Spanish, and the church and the government buildings, were to be tiled rather than roofed in the traditional Andean fashion with ichu thatch, for tiled roofs were much safer in case of fire. Kurakas were to receive two lots; commoners one, unless the family were very large, then they could get two. There were to be structures of two or three rooms, so that parents and their children would not have to sleep together, which Matienzo believed led to great evil. They should sleep on mats rather than directly on the floor. ${ }^{11}$

The corregidores de indios were in charge of the implementation of the settlement policy, a test of their authority and the political strength of the maturing colonial system. The settlement took place concurrently with Francisco de Toledo's general inspection and census of the realm. In the Colca Valley, the reducciones were directed by corregidor Lope de Suazo in the years between 1571 and 1574. Lope de Suazo "reduced" 33,000 valley residents into 24 new pueblos de indios. This was roughly a third of the native population of the entire district of the city of Arequipa. Unfortunately, we lack documents describing the daily activities of Lope de Suazo during these critical years in the history of the valley. We do not know the reasons why one site for the foundation of a town was chosen, rather than another. Nor do we know why particular ayllus were congregated, or how they were integrated into the dual system. ${ }^{12}$

In a letter of 1570, Toledo wrote to the king detailing the reasons for the establishment of the reducciones. The new villages would allow for more successful indoctrination and better collection of tribute, something the king could appreciate. Further, native idolatries and drunken fiestas could be more carefully controlled. The best size of community was one of 400 tributaries, about the same as recommended by the Second Church

11 Matienzo, Juan de: Gobierno del Perú (1567), Guillermo, Lohmann Villena (ed.), Institut Français d'Etudes Andines, Paris, 1967, págs. 48ff.

12 Este proceso es descrito en forma detallada en AGI, Lima, 28A; AGI, Lima, 29; BNL, B 511C. En Huarochirí el primer corregidor Lorenzo de Figueroa no podria terminar la reducción de la provincia. Finalmente, después de diez años de esfuerzos, el corregidor Diego Dávila Brizeño finalizó las reducciones allí. Véase Spalding, Karen: Huarochirí, an Andean Society under Inca and Spanish Rule, Stanford University Press, Stanford, 1984, pág. 81. 
Council. Toledo told the king that the reducciones had already been undertaken in Cajamarca, but he needed to do it over again there into larger and fewer villages. He noted the difficulty in the process; the corregidor and officials there had been "lazy", and there had been an explosion of legal proceedings involving the Indians. ${ }^{13}$ Three years later, with considerable experience in congregating the Indians behind him, Toledo was able to issue more specific regulations for his appointees conducting the settlement process. He notified Captain Loyola, who was named to undertake the reduction of the Indians of Quilcaquilca in La Plata, that he should consult with the kurakas and the lesser Indians, as well as the priest, but warned Loyola not to be swayed by the requests of the kurakas and the encomenderos. He was ordered to conduct a careful survey of the village site, to make sure there was adequate water, firewood, pasture, and that the site was a healthy one. He was warned not to let the Indians build where their ancestors were buried, and to be aware that the Indians would resist the move no matter what steps he took. The village's ideal size was to be if at all possible, between 400 and 500 tributaries. The viceroy instructed Loyola to admonish the kurakas that they could forfeit their positions if they did not cooperate. Toledo further told the appointee that he should not allow anyone to bring suits to him for a hearing regarding the move. ${ }^{14}$

The process was difficult for the native Americans; they were uprooted from their homes and huacas, and forced to build new communities and houses, adding an additional burden to the ubiquitous obligations of agriculture and tribute. The kurakas and the principales of the Colca Valley obeyed the orders and collaborated in the concentration of the commoners into the villages in order to maintain their own position in the new structure. The few kurakas in the Andean region who refused to lend their support and revolted lost their administrative role, and some were exiled from their native communities. The Colca kurakas assumed their positions while assisting in a process that broke old ties and helped forge a new settlement pattern in the valley. ${ }^{15}$

Coporaque, the principal village in the valley in the pre-Spanish period, was expanded by the inclusion of seventeen communities and

13 Vargas Ugarte, Concilios Limenses, vol. 1, pág. 249; AGI, Lima, 28A.

14 AGI, Lima, 29.

15 Entre los dias 22 y 25 de enero de 1574 Rodrigo de Cantos Andrada, visitador de las provincias de Lima y Huamanga, condenó a algunos caciques e indios principales del repartimiento de Huarochirí por regresar a sus asentamientos anteriores. Las multas cubrieron parte de los costes de la visita; véase AGI, Contaduría, 1785. 
ayllus scattered in that section of the valley. No record, other than the names of the units, has come into view explaining the rationale behind the incorporation of various ayllus into the new residential pattern, nor of the rationale for the placement of some Indians in anansaya, and others in urinsaya. The new community of Chivay was created by the congregation of Indians from Canocota, Huacallihua, La Calera (thermal baths), Huyrapucco, Uscallacta, and Cumuranc. ${ }^{16}$

Native Americans up and down the valley, ayllu by ayllu, hamlet after hamlet, were concentrated into the new villages by Lope de Suazo during his three year tenure as corregidor. By the time the process was completed in 1574, there were only a handful of pueblos de indios, instead of the dozens of the pre-conquest era. The Indians living in the puna above the valley floor were forced to descend, to become villagers, at least part of the year. A total of some twenty-four pueblos were created by Lope de Suazo in the province of Los Collaguas during the settlement years. In keeping with the approximate distribution of the population in the corregimiento's repartimientos, eight pueblos de indios were established in the lower valley, under Cabanaconde; six in Lari in the middle valley; and ten under Yanque in the upper valley. The names given to the pueblos at the time of the visita general often included a Spanish one, as well as a native, for example, Oropesa de Tisco. We are unsure of the reason for the choice, but we can suspect, in certain cases, that the name referred to places the corregidor knew, or perhaps the local clergyman, or encomendero. Oropesa, for example, was the birthplace of Viceroy Toledo. Cabanaconde was "Hontiveros", the homeland of Colca Valley encomendero Diego Hernández de la Cuba. The name "Hontiveros" soon disappears from the record, and we know Cabana from only its original name, Cabana, or Cabanaconde. In fact, all Spanish village names are erased in the valley, and quickly, save for the singular case of Madrigal, perhaps named after the birthplace of Queen Isabel the Catholic.

In spite of the choice of Yanque as capital of the recently created corregimiento of Los Collaguas, we are unsure of the names of the hamlets from which it was formed. The forced creation of the Toledo towns must have left a significant and lasting imprint on those who experienced the chaotic process. Such an upheaval, although relatively undocumented in

16 Málaga Medina, “Los Collaguas”, pág. 101. Málaga (comunicación personal, junio de 1991) reconstruyó los nombres de muchos de los ayllus a base de un documento en mal estado de conservación en el Archivo General de la Nación, pero no contenia información sobre el pueblo de Yanque. 
the written record, was remembered by generations of valley residents and became part of a mythic past. Contemporary Yanque oral tradition holds that the original settlement's name was La Brota, and that the principal family was the Choque, or Choquehuanca. That family had friends, the Checas, "perhaps they were even godparents", on the other side of the valley in a village whose ruins are today called Yanque Viejo (Ullo Ullo). The present community was created as the Choquehuancas invited the Checa family to live with them in La Brota. The Checas crossed the valley to live with the Choquehuancas, taking along with them their religious image. The image was carried on foot, to the floor of the canyon, taken across the river, and ceremoniously placed in the new church of La Brota. But the spiritual forces of the original home exercised their powers. "The next day they went to see the image, and it was no longer there, it had disappeared, the image had returned there (to Yanque Viejo), where it had been." According to the legend they carried the image from Yanque Viejo to La Brota three times, and three times it returned by night. They locked the church doors and posted guards, but to no avail. Villagers maintain that the last time they crossed the river, where there is the small calvarito, the image had blood sprinkled on it. ${ }^{17}$

This contemporary oral version of the formulation of Yanque has some foundation in historical reality. The Choquehuancas and Checas appear in remaining seventeenth century parish registers of Yanque. The Choquehuancas were probably the foremost family in Yanque anansaya, site of the pueblo of La Brota that was the core of the new Toledo settlement, while the Checas were the leading family of Yanque urinsaya. Even today most of the agricultural lands of Yanque urinsaya are located on the north side of the Colca River. Daily, as in the time of the Toledo reducciones of the 1570s, many of the residents of Yanque urinsaya set out early in the morning for the roughly hour long trek down the canyon, to cross the river, and climb the steep north bank to the agricultural fields of Yanque Viejo. On the south side, in "new" Yanque, agriculturalists still complain of the lack of water. Prior to the Toledo foundation, there was enough water for the inhabitants of both sides of the valley. The new settlement pattern required a greater volume of water on the south side of this sector of the valley because of the increased population density. ${ }^{18}$

17 Pease, Franklin: "Collaguas: una etnía del siglo XVI", en Franklin, Pease (comp.): Collaguas I, págs. 153-56

18 Investigaciones en el campo, Colca Valley, 1977. 
The contemporary visitor, who ascends the north side of the valley, and enters the ruins of the village of Yanque Viejo, or Ullo Ullo, cannot but be struck by the size of the site and its large, well-constructed buildings. House after house, from one level or terrace upward to the next, punctuate the slope. The pre-conquest town was well laid out in order to capture the maximum sunlight, with an excellent and commanding view of the south side of the canyon. The people of Ullo Ullo were uprooted by Lope de Suazo and forced to relocate to the south side of the river and build new homes. In so doing the colonial state was attempting to erase the memory of the villagers and forge a new socio-politico construct on the colonized. The temptation to remain in their native village was strong. Some may have initiated a return, perhaps making the attempt three times, as related in the myth. But the corregidor and kurakas made certain the return was unsuccessful. Their old houses, if necessary, were torn down. The officials of the new regime ultimately prevailed and Ullo Ullo was forever abandoned. Yet the descendants of the forced Lope de Suazo - Toledo migration continue to plant, cultivate and harvest their crops in what were the living compounds of their ancestors. And the memory of the forced move was not silenced, rather it persists long after the end of the Spanish empire. What is erased from the cultural memory of the contemporary Cabana and Collagua is the name of the organizer, Viceroy Toledo, and his subordinate corregidor Lope de Suazo, who carried out the policy in the valley.

Spaniards Juan de Matienzo, Francisco de Toledo, and others were attempting a New World experiment of Renaissance town planning on a massive scale. In the Colca Valley, as well as elsewhere in the native Andean countryside, the colonizers were "constructing" hundreds of European towns in the land of not yet "civilized" peoples. In the European's mind, these new towns symbolized order, rather than the chaos of the barbarian world. The structure of the new Renaissance "pueblo de indios", with its grid-iron pattern of streets intersecting at right angles, with a public plaza in the center, with the inevitable church and municipal buildings at the core, represented order, civilization, Christianity. The corregidor could feel at home, secure at the center, surrounded in an alien world by familiar structures, demonstrating the power of Imperial Spain.

The new towns were built by Andean Americans under orders of the colonial bureaucrats. They were constructed during hours, days and weeks stolen from the normal agricultural cycle. The location of the new villages forced the residents of the Colca Valley to spend extra time commuting to 
their fields, week after week, year after year. The new structure meant supervision under the inquiring scrutiny of the clergyman and corregidor. The housing compounds were open to the streets, the passing outsiders could monitor and control events inside. Concubinage, possible in the small isolated hamlet, became difficult to hide from the prying eyes of the priests. The rites and ceremonies of the pre-Christian era, that could be supported in the distant countryside, were much more difficult to maintain in the towns. Further, the towns turned out to be dirty, the problem of pure drinking water was compounded by larger population density. And diseases seemed to spread more rapidly through the towns than in the fields and puna. The European's utopian Indian community became another instrument in hegemonic control over the native American. In many areas of the Andes natives simply fled, or returned to the countryside or puna as quickly as the town founders departed. Such was not the case in the Colca Valley where the towns took hold and persisted, some continuing into the present, looking very similar to the way they did when established in the 1570s.

In order to understand how the system functioned in the Colca Valley, and why the corregimientos de los indios were preferred by the Crown instead of the encomienda system, it is instructive to examine several specific cases. Detailed information on the administration of some corregidores is provided in their residencia records. Most Crown officials, even viceroys, were subjected to the residencias, official inquiries into their activities at the end of their term in office. In the case of corregidores, the replacement generally conducted the inquest. Public notice was given by town criers, and anyone had a specified number of days to enter charges against the official. Charges could cover a wide range of issues: absenteeism, excessive collection of tribute, engaging in illegal economic activities, failure to oversee justice or make certain that the doctrina was being administered, marriage to local Spaniards, or failure to ensure the laws were properly administered. Virtually anything the corregidor did could come under scrutiny. After testimony, if warranted the official could be fined, imprisoned, exiled, or barred from future public service.

The residencia did prevent abuses, and many of the corregidores, and other Crown officials performed their work diligently and honestly. But most were inclined to amass as much wealth as possible in their short tour of duty in the Andean countryside. Lucas de Cadabal provides an instructive case. His tenure in the province of the Collaguas, beginning in 1581 is detailed in the residencia taken by his successor, Juan de Ulloa Mogollón 
early in 1584. Caylloma-based priest Sebastián Durán, who served as Lari's doctrinero in the repartimientos of Picado and Retamoso, testified that Cadabal was especially diligent in his efforts to extirpate idolatries and witchcraft. The Indian scribe of Yanque Collaguas, Diego Coro Inga, testified that Cadabal discovered and destroyed huacas, and punished Indians who persisted in pre-Christian rites. Lucas de Cadabal was also instrumental in the cultivation of wheat in the valley. Durán reported that with great persistence and effort, the corregidor had forced the Indians to plant and cultivate wheat, causing it to become a major valley product. Francisco Ala, alcalde ordinario of Yanque, said that before the arrival of Cadabal it was necessary to "bring in the wheat and bread from the city of Arequipa and the valley of Pitay, and other parts as far away as twenty leagues...." But now bread was plentiful. Yanque resident Antonio Fernández stated that wheat was presently cheaper than in Arequipa or Pitay. A grist mill had been built in Lari, through the efforts of Cadabal. Lari kuraka Don Marcos Suyo boasted, "...in the pueblo of Lari there is a mill which is so good that it is able to grind anything that is necessary for the whole province...." Cadabal also assisted the Indians to plant community fields to aid in increasing revenues. Francisco Hernández said that before Lucas was corregidor, there were no community goods, but "now all the said communities are rich and support hospitals and doctors...." Cadabal also led in a search for new mines in the province and saw to the completion of tambos, cabildo offices, and bridges. Scribe Diego Coro Inga said that the corregidor completed major public buildings in the province that were started during the Toledo reducciones. Durán asserted that Cadabal was a just person, ensuring that the Indians paid tribute equally according to the number in each ayllu and that the Indians liked him better than previous corregidores. The assessment that "he leaves the province a poor man, taking with him only his salary...." is one of the most eloquent recommendations a corregidor could receive. The glowing evaluation of the accomplishments of Lucas de Cadabal is largely the result of policies that stood to benefit the colonists and Crown as much as the native residents of the valley. His activities guaranteed that the Spanish colonial regime would benefit future generations of Europeans. ${ }^{19}$

A substantial part of Lucas de Cadabal's time was spent collecting tribute and dispensing the money to various individuals as allocated in the

19 ANP, Residencias 5, cuaderno 9. 
assessment. When Juan de Ulloa Mogollón, the newly appointed corregidor began his inquiry into the administration of Cadabal he called in the two Indian keepers of the keys of the community treasure chest in Yanque. Juan Alanoca and Pedro Auca were requested to open the box before witnesses Gonzalo Gómez de Buitrón, Pedro de Puerta, and notary Martín Gutiérrez. Contents included the account books and the reserves of the previous corregidor, Josepe de Villalobos, and his predecessor Juan Durán de Figueroa, as well as an earlier corregidor, Juan de Vergara, with tributes from the first payment of Christmas of 1575. Three pay periods of Lucas de Cadabal for San Juan of 1582, Christmas of 1582, and San Juan of 1583, were audited. These were based on a new tribute assessment established by Viceroy Martín Enríquez.

The account books covering income and expenditures provide one window on the daily existence of the valley's people as well as their administration. Corregimiento expenditures for Yanque Collaguas included salaries of 3,524 pesos, 6 tomines for Franciscan doctrineros. There was also a sum of 3 pesos, 2 tomines, paid to Father Muñoz for the purchase of a blank book to record doctrina revenues. Again, the fact that some 375 pesos were paid for Church salaries in La Chimba (250 pesos yearly) where many migrants from the Colca Valley temporarily resided, is expected, for it is based on the assessment. But what is surprising and informative is that 48 pesos, 6 tomines had been returned to the treasuries in Lari urinsaya and Cabana urinsaya because the Indian justices had been overpaid! Then, 11 pesos, 2 tomines were transferred to the Arequipa treasury to Dr. Cosme Carillo because of an accounting error. The corregidor had been paid a salary of 1,138 pesos 5 tomines from the Yanque treasury for the period 10 February 1582 to 15 December 1583 . The defenders and protectors of the Indians were paid 526 pesos, 4 tomines, during Cadabal's term, at a yearly rate of 351 pesos. The Indian hospitals received 567 pesos, 5 tomines, but that sum had been paid to Hernando Cornejo, the surgeon of the province, at a rate of 400 pesos annual salary. In addition, almost 300 pesos were paid out for hospital supplies: oil, figs, sugar, honey, physics (purges), Paris green, solimán, and other products. Further, the kurakas and principales received 1,320 pesos ( 880 pesos yearly stipend).

The flow of tribute revenues through the hands of the corregidor provided ample opportunity for personal profit. Control over the mitayo labor force of the various repartimientos in the corregimiento gave the official even greater authority. Not all corregidores managed to resist the tempta- 
tions. In 1596 Diego Peralta Cabeza de Vaca became the new corregidor. He was encomendero of Capachica in Upper Peru, and he was a rich mine operator, controlling silver deposits in the province of Sica Sica near La Paz. Furthermore, he had a family in Arequipa and was active in commerce, with stores and land. As corregidor, he illegally attempted to use Collaguas mitayos to work in his own mines at Sica Sica, but almost immediately was blocked in his efforts by the intervention of Arequipa's cabildo, which viewed his action as a threat to their own supply of mitayos. ${ }^{20}$

Viceroy Toledo's tribute assessment and following payment records illustrate the wealth passing through the hands of the corregidor, wealth far exceeding his modest salary, and thus very tempting as he strove to profit by his administrative position. Review of a set of records for one of the repartimientos in the valley is instructive. Tributaries were in theory males from the age of 18 to 50. Elders were reserved from payment of tribute, as were the kurakas and these two groups may have constituted approximately one-seventh of the population. Men who were too ill or infirm, the blind, crippled, or those without limbs were also exempt. It is difficult to judge the exact number withdrawn from tribute status by illness or infirmity. In the ayllu of Coporaque urinsaya pahana taypi pataca in 1604, there was a forty-year-old exempt as crippled, a thirty-eight-year old with a broken leg, a thirty-year-old with a heart problem. There were 37 in the ayllu of tribute paying age. The principal was exempt, as was the native school teacher. The latter two were listed in the section with the tributaries. The three "infirm" within the same age category were on the list of "viejos and impedidos." But the same visitador included the ill with the tributaries in the next ayllu. The Indian teacher was exempted. The hospital levy was part of the tribute load, a simple payment of one tomín per tributary head. The hospital quota was uniform throughout the Andean world, in contrast to the tribute rate, which varied slightly from one repartimiento to another, and was based in part on the assumed capacity to contribute. ${ }^{21}$

Based on the tribute structure instituted by Viceroy Toledo in 1572, the most important asset for the Crown in the Colca Valley was the repartimiento of Yanque Collaguas. The anansaya half was required to contribute 4,962 pesos of silver, and urinsaya 3,030 pesos. Further, anansaya Indians were to weave 2,000 pieces of abasca cloth, half for men, and the other half for women. The cloth was valued at two and one-half pesos each

20 Ibidem.

21 Archivo Parroquial de Yanque. Visitas 1604. 
piece, for a total value of 5,000 pesos. Cloth was a major product in the colonial economy, one that was marketable in Lima, the mining centers, and could be exported to Chile and beyond. In addition to cotton, there were two types of woollens: cumbi and abasca. The cumbi was of the very finest wool, tightly woven, with elaborate designs, and it was highly prized. The abasca was common cloth, and provided the normal worker's garb. Karen Spalding describes the typical Andean clothing, that: "consisted of straight panels that when shorter and narrower were turned into breechclouts and sleeveless shirts for men, and when longer and wider were wrapped around the body and pinned for women." The urinsayas were to provide 1,220 "pieces" of cloth worth 3,050 pesos. In addition, anansaya was to pay in tribute 481 llamas worth 1,202 pesos, 4 tomines; and urinsaya 295 llamas valued 737 pesos, 4 tomines. The total annual tribute was 17,982 pesos. But there were costs that the Crown had to deduct. Some 3,450 pesos were subtracted for the "stipends" of the eight Franciscans who served in the repartimiento and the clerics who served in La Chimba. A further 2,515 pesos were taken away for the payment of the legal "defenders" of the Indians; and 600 pesos for the Indian hospitals in the repartimiento. The kurakas were paid 880 pesos from the tribute. The Royal Treasury was left with a hefty annual income of 10,537 pesos after expenses. ${ }^{22}$

Tribute was collected twice yearly in the Colca Valley, as was customary elsewhere. The dates of payment were Navidad and the day of San Juan, 24 June. The kurakas were responsible for the collection of the tribute; they in turn transferred it to the corregidor. Local treasury books are filled with entries such as the following: "Item. We have taken charge of 970 assayed pesos in reales of $12 \frac{1}{2}$ reales per peso that were received from the Collaguas Indians of Your Majesty on 7 August 1583, for the 388 carneros de la tierra (llamas, alpacas) for six months beginning on San Juan of 1583 at a rate of 2 pesos 4 tomines for each animal, in conformity with the assessment found on page 141." ${ }^{23}$

The goods that the Indians were required to contribute were assessed at a monetary figure that often had little relationship to real market values. When market prices rose substantially above the assessed figures, the Indians often attempted to sell the goods themselves, and then substitute a

22 AGI, Contaduría, 1786, editado por Cook, Noble David (ed.): Tasa de la visita general de Francisco de Toledo [1571-75], Universidad Nacional Mayor de San Marcos, Lima, 1975; Spalding: Huarochirí, pág. 133.

23 ANP, Residencias 4, cuaderno 8. 
monetary payment (the process was known as commutation) rather than the goods. For example, in the June payment of 1584, tributaries gave 970 silver pesos for the llamas, "because they did not bring in the articles as customary for the said period, day, month, and year." The Collaguas tributaries were quick to learn the way the European imposed system worked, and were adept at using it to their own advantage whenever they could, just as they learned to use the colonial legal system to protect and extend their rights. ${ }^{24}$

Officials were often reluctant to accept commutation, because they faced loss of a substantial supplementary income. For example, the abasca clothing assessed at $2 \frac{1}{2}$ pesos was sold by the treasury officials to Juan de Salazar for the six-month payment period (tercio) ending Christmas of 1583 for 3 pesos, 7 tomines. In the June tercio of 1584 the cloth was purchased by Antonio de la Cuba at a figure of 3 pesos, 4 tomines per piece. The following Christmas tercio the Collaguas cloth was sold to Antonio de Oviedo for 3 pesos, 2 tomines each piece. The tercio payment for June of 1585 was acquired by Antonio Hernández at a price of 3 pesos, 3 tomines. The same figure applied for the following sale for the Christmas tercio. The San Juan of June of 1586 sale was made to Francisco de Almonte at 3 pesos, 7 tomines. In 1591, the sale price was about 3 pesos, 1 tomin per piece. We see constant fluctuations in the "wholesale" price of the abasca cloth, but at levels substantially higher than the tribute rate of 2 pesos, 4 tomines. The "retail" price was even greater than the wholesale. The cloth was often transported to the mining centers, to Potosí, for example, and sold at inflated prices. Market conditions could and did vary, but given the profits that could be made, both the Crown and private merchants preferred payments in kind, rather than commuted to cash. ${ }^{25}$

Commutation of cash for goods was resisted by those who stood to profit most by the system. The passion of their arguments is highlighted in a memorial to the viceroy composed by Luis de Peralta, procurador general of Arequipa, in the name of the cabildo: "Because of the commutation to silver instead of contributing in kind, much hunger has resulted, and there is a lack of common necessities of the realm, particularly in the city of Arequipa, because by freeing the Indians from paying their tax in kind, they do not plant or grow, or work more than only enough to earn the tribute money... from this are born idolatries, drunkenness and incest, which are so carnal that neither mothers nor sisters are spared, and the Republic 
suffers...." Viceroy Luis de Velasco was persuaded by this petition, and he issued an order on 7 May 1597 for the Indians to pay as required in the assessment, but if the corregidor allowed commutation, he was to provide a full explanation. ${ }^{26}$

The precious metals, gold and silver, that are included in the tribute assessments have puzzled researchers, because the source for this monetary payment was not specified. Some tributary Indians worked for outsiders for a wage, and others sold products in the open market to secure cash to cover the tribute assessment. In the case of the tributaries of the Colca Valley, it is now clear that modest deposits of silver ore and gold nuggets or dust were regularly exploited, although at a household level. The Royal Treasury records of the 1580s provide evidence that the native Americans searched for silver deposits, and promising good concentrations of gold in the river beds. In the case of Yanque Collaguas, in 1586 Gabriel Ala brought in 3 marks, 3 ounces of worked silver to be assayed. The total value was 7,593 maravedies, part of this was deducted for assay costs. Juan Ala deposited 1 mark, 100 ounces, worth 3,656 maravedies. On 26 February 1586 Felipe Yaure tendered 5 marks, 2 ounces, which was converted to 11,812 maravedies. Don Diego Chacha and Juan Poma deposited 10 marks, 6 ounces. Diego Chapi converted 7 marks, 5 ounces, and on 10 April 1586, Pedro Chicha gave 9 marks, 2 ounces. Don Francisco Ynga Pacta gave 7 marks; Don Diego Chuquianco 5 marks. One of the largest assays of the period from Yanque Collaguas was made by don Juan Alanoca on 27 April 1586: 20 marks, 2 ounces, that converted to 45,562 maravedies. In all cases the fee for marking was one percent, (456 maravedies in this case), then the diezmo was subtracted from the remaining amount (4,510 maravedies in this example). Colca Valley women also brought in precious metals to be assayed and marked. Ynés Vilca presented 2 marks, 3 ounces. According to the treasury data at times substantial amounts of precious metals were tendered by the tributaries of Cabana lower in the valley. For example, in 1586, don Francisco Antiala, kuraka of Cabana, gave 57 marks, 7 ounces of worked silver worth 129,818 maravedies, and 198 pesos of gold, that was converted to 111,375 maravedies. ${ }^{27}$

Profits could be extracted from the tribute system by those who manipulated the native American contributors. At the time of the residencia of Juan de Ulloa Mogollón who had been corregidor in the province of Los

26 BNL, B 415.

27 Ibidem. ANP, Residencias 4, cuaderno 6. 
Collaguas for five or six years, several individuals charged that he had illegally earned 30,000 pesos. The corregidor had at one time suggested to the kurakas that they collect the livestock required in tribute directly from the tributaries. They could then sell it at the market for a typical price of $51 / 2$ pesos per head, and sometimes even 6 or 7. Many in the valley collaborated in this scheme. Both Gonzalo de Buitrón, a mestizo who had been in the Collaguas from about 1574, and Hernando Alonso de Badajoz, who lived in the house of the corregidor, participated in the venture. Some kurakas and principales were also involved. For example, Kuraka Francisco Maqui took Indian herders and llamas to Potosí, where the animals were sold. Juan de Ulloa Mogollón sold 400 fanegas of corn from community lands to his friend Hernando Alonso de Badajoz, who then transported the corn to Carabaya, a rich gold mining area on the eastern slopes of the Andes, and sold it there for 5 pesos per fanega. Furthermore, with the complicity of corregidor Ulloa Mogollón, Hernando used Collaguas Indians to transport wine from coastal vineyards to the Canas province, and even as far away as Cuzco, to be sold. ${ }^{28}$

Colonial officials could profit during the sale of tribute goods in various ways, though many were illegal. For example, Sebastián de Mosquera was acting as a contador in Arequipa in the 1590s. Various charges were made against the official at the time of his residencia. The Royal Audiencia appointed Doctor Chacon to investigate the case, and the decisions were issued in Lima in 1598. During his term of office, Mosquera had sold at public auction Collaguas cloth to merchant Pedro de Vera, and had allowed the merchant to make a delayed payment, rather than cash. It was revealed that another merchant, Hernando de Argomedo would have immediately paid the Crown official cash for the cloth. But Mosquera sold the goods to Pedro de Vera, and for the favor received a kickback of one tomin per piece of cloth. ${ }^{29}$

The European tribute system was different from the Inca. Control over and access to labor and goods of the Colca Valley during Inca rule was tempered. The Collaguas and Cabanas in the Inca state existed within the Andean framework of reciprocity. The outflow was minimal, and there was compensation in the form of access to power within the Inca bureaucratic structure. In the Spanish colonial system, on the other hand, the outflow of

28 ANP, Residencias 4, cuaderno 8; Crespo, Juan Carlos: "Los Collaguas en la visita de Alonso Fernández de Bonilla", en Pease, Franklin (comp.): Collaguas I, págs. 55-56.

29 Ibidem. 
labor and goods was incessant, and the quantities demanded were far in excess of what had been required under the Incas. The storehouses, or colcas, were emptied to help fill the insatiable demands of both individual Europeans, and state policy that was more concerned with foreign affairs than with the welfare of the native American. ${ }^{30}$

Resistance to the foreign masters tended to be passive but effective. In the case of the Colca Valley and elsewhere as Stern documents Andean peoples quickly learned to use the Spanish administrative and judicial system to their advantage. The judicial system in general did work to afford protection and the office of the "Protector de los Indios" sometimes functioned as it was designed. The Church in many places acted as a buffer between exploiter and exploited. The Collaguas found some support from the Franciscans friars who because of their rejection of the material world often tried to protect their charges from incessant demands of settlers and bureaucrats. Other repartimientos in the valley were less fortunate in this respect. ${ }^{31}$ Colca Valley residents resisted in many ways. They delayed payment of tribute, they fled, and they frequently subverted the system by providing inferior tribute goods. They often obeyed the quota but provided minimal products. Mitayo labor, in spite of the clamor of the settlers for service, must have been notoriously inefficient. Forced work does not generate maximum productive capacity. It is no wonder the Spanish characterized the Indians as "lazy," the same adjective given by slave owners in the ante-bellum South of the United States to their plantation laborers. ${ }^{32}$

There are several examples of resistance in the adjoining repartimientos of the Majes and Ubinas provinces. Pedro de Puerta, the official in charge of tribute collection in the period from 19 July 1566 to mid-June of 1570 , complained of the quality of tribute goods from the repartimiento of Ubinas: "the said cloth is of the meanest kind, and is of less price and value than any other... of the city of Arequipa. And in effect it is and has been because the said Indians make them with the vicuña wool, rough and coarse, and that of cotton is also coarse and poorly made, and the lliquillas of the one and the other are small, of 3/4 of a vara in length, as half lliquillas." The highest punalands of both the Ubinas and the Collaguas today provide

30 Wachtel, Nathan: Sociedad e ideología. Ensayos de historia y antropología andinas, Instituto de Estudios Peruanos, Lima, 1973, págs. 130-48.

31 Stern, Steve J.: Peru's Indian Peoples and the Challenge of Spanish Colonialism. Huamanga to 1640, University of Wisconsin Press, Madison, 1982, págs. 114-37.

32 Wightman, Ann M.: Indigenous Migration and Social Change. The Forasteros of Cuzco, 1570-1720, Duke University Press, Durham, 1990, pág. 24. 
excellent pasturage for the vicuña, which provides some of the finest wool there is, but this sixteenth century bureaucrat found their wool to be of little value. Of the wheat paid in tribute by the Ubinas Indians, Pedro de Puerta lamented that it is "sierra wheat, small and dark, and not as good as the rest of the wheat that there is in the city of Arequipa." The chili peppers, or ají, were likewise of poor quality, according to the frustrated corregidor. Especially revealing are his comments about the hens: "they are small and skinny birds taken down from the sierra, and the Indians are accustomed to giving the worst that they have." The complaints about the Majes are similar: "the Indians generally are accustomed to giving the worst they can find, some are old and skinny, others small hens and cocks, and those of the sierra of little value." Of the coca leaves from the Majes repartimientos Pedro de Puerta charged: "it is coquilla of a small and yellow leaf, similar to the valleys of Lima and the others of the yunga [coastal lowlands], and is nothing like that of Cuzco. They are called by the Indians toxa, and the cestos are so mean and bad that they give in tribute, they.... are small, light, and of little coca." Later, in 1573, Puerta complained that he was trying to force the nearby Ubinas tributaries to pay him "quickly" the 160 pesos "they owe." It is possible that Puerta was committing fraud, that he was trying to cover up the fact that he was receiving more in goods than mandated in the assessment, and that his complaints were a subterfuge to throw officials off the track. But, passive resistence in the form of late tribute payment, or in contribution of inferior goods, technically helped the Ubinas, Collaguas and Cabanas to subvert the colonial system. ${ }^{33}$

Corregidores of the Colca Valley also faced economic challenges, for although they had status, stipends were often inadequate to cover the high costs of transportation to America and setting up a household in Arequipa. Many corregidores intended to take their families to the Indies, hoping to marry relatives to members of the wealthy creole elite. The example of Diego de Treves y Brito stands out. Philip II (Aranjuez, 16 March 1586) named him corregidor of Arequipa and the Collaguas simultaneously, a dual appointment. On 20 August 1586 the king wrote Peru, explaining to Viceroy the Conde del Villar his reasons for this unusual step. The corregidor's father had been in royal service for over fifty years, and Treves y Brito had served as page in the royal court during his youth. The corregidor

33. AGI, Justicia, 448. 
slowly prepared his household for the long journey to Peru. He requested permission to take with him and his entourage 100 arquebuses and other equipment, offering to pay transport costs. He explained that he brought the weapons "because that land is a frontier that could be infested with corsairs. ${ }^{\prime 34}$ But he expected to sell the arms at a profit. They did not sail for two years because of delays caused by Spain's preparations for the 1588 Armada. When the corregidor's group reached American soil, several fell ill in Tierra Firme. They were delayed on the final southward voyage to Lima by "poor navigation." Treves y Brito's stay in the viceregal capital was equally frustrating. The Conde del Villar had been replaced by García Hurtado de Mendoza, the second Peruvian Marqués de Cañete, and the new viceroy refused to assign simultaneously Treves y Brito two corregimientos, correctly insisting that it was contrary to prior royal decrees. Furthermore Cañete reduced his salary. The corregidor was shocked by this turn of affairs, and wrote a long letter of complaint to the sovereign. $\mathrm{He}$ lamented he had expended more than 20,000 ducats to transport himself and his entourage and that he was heavily indebted. He finally assumed his post in Arequipa in late 1590, and continued to lodge grievances, complaining "the salary is so small and the land so poor." He noted that Viceroy Cañete had restored the alcabala in the district, and that it was causing much hardship. With the "calamities of the earthquakes, pestilence, moving the port, the lack of transport for the wine," conditions in Arequipa were deplorable. Treves y Brito continued his efforts to secure joint appointment as corregidor of Arequipa and the Collaguas, writing that other men in the Indies had served in dual posts. Finally, the corregidor's financial position in Arequipa was improved as a marriage agreement that linked two families was signed with Gerónimo de la Cuba Maldonado, encomendero of Cabana anansaya. With the eligible Doña María de la Cuba Maldonado came a substantial dowry of 30,000 pesos. ${ }^{35}$

By the second decade of the seventeenth century, in the Colca Valley and elsewhere in Peru, there were notorious abuses of the system by many corregidores. In spite of the threat of the residencia to uncover graft and corruption, inadequate salaries coupled with the view that public servants ought to be rewarded for their services, resulted in wrongdoing. In a report to the king, one official argued that corregidores were actively engaged in economic pursuits, and rather than protecting the natives, the corregidores

34 AGI, Indiferente General, 2097, núm. 153.

35 AGI, Lima, 131. 
were exploiting them. Some corregidores established textile factories, others took native cloth goods as payment for tribute that were assessed a 2 pesos per piece, then sold for seven to eight pesos. The residencia, designed originally to check abuses of public officials, was not functioning as intended. The Royal Audiencia (Lima, 18 May 1616) reported that corregidores were deeply involved in the control of local branches of the Royal Treasury office, engaged in illegal trade in cloth, wine, livestock, and other goods, and were closely confederated with other Spaniards and kurakas in the Indian provinces. The natives during the residencia "tempered their complaints in order not to fall from grace from the incoming corregidor." The native American leaders, fearing for their own positions, often chose to accommodate and thus protect their own interests. ${ }^{36}$ But no matter what the level of corruption, the system was more attune to maintaining royal authority in the Indies than the encomienda had been. The loyalty of the salaried public officials in the Andean countryside was unquestioned. In contrast, a permanent hereditary encomendero elite would have inevitably led to a break with the homeland. In this important sense, even recognizing the abuses, the corregimiento system was a success for the imperial cause. But for Andean peoples both the encomienda and the corregimiento were authoritarian, exploitative, and alien.

36 AGI, Lima, 95. 


\section{Cuadros}

CUADRo 1

CORREGIDORES OF LOS COLLAGUAS EN EL SIGLO XVI.

\begin{tabular}{llc} 
Corregidor & Fecha & Años en oficio \\
\hline Juan de la Hoz & 1566 & 5 \\
Lope de Suazo & 1571 & 7 \\
Juan de Vergara & 1578 & 1 \\
José de Villalobos & 1579 & 3 \\
Lucas de Cadabal & 1581 & 2 \\
Juan de Ulloa Mogollón & 1583 & 7 \\
Captain Gaspar Verdugo & 1590 & 1 \\
Gaspar de Colmenares & 1591 & 2 \\
Pedro Quiroz & 1593 & 3 \\
Diego Peralta Cabeza de Vaca & 1596 & 4 \\
Dr. Gonzalo Rodríguez de Herrera & $1600^{*}$ & \\
\hline
\end{tabular}

*Todavía en oficio 30 de diciembre de 1605, Archivo del Convento de San Francisco de Lima, registro 15 , fols. $487 \mathrm{r}-98 \mathrm{r}$. 


\section{CuAdro 2}

PUEBLOS DE INDIOS REDUCIDOS POR

EL CORREGIDOR LOPE DE SUAZO, 1571-74.*

\begin{tabular}{cl} 
Repartimientos & \multicolumn{1}{c}{ Pueblos } \\
\hline Cabana & Hontiveros \\
& Las Broças \\
& Oviedo \\
& La Puente del Arzobispo \\
& Pampamico \\
& Guanca \\
& Lluta \\
& Yura \\
& Talavera de Lari \\
& Las Broças \\
& Paradines \\
& Madrigal \\
& El Puerto de Arrebatacapas \\
& Miraflores \\
& Corral de Almoguer de Yanque \\
& Villacastín de Coporaque \\
& Achoma \\
& Martín Muñoz de Chivay \\
& Villanueva de Alcaudete de Coymo \\
Yanque & Espinar de Tute \\
& Alcántara de Callalli \\
& Utrera de Cibayo \\
& Oropesa de Tisco \\
& Caylloma \\
& \\
&
\end{tabular}


CuAdro 3

“AYLLUS" REDUCIDOS EN COPORAQUE POR LOPE DE SUAZO, 1574.*

\begin{tabular}{lll} 
1574 nombre & Nombre contemporáneo & Número de "casas” \\
\hline Tunsa & Tunsa & 6-7 casas \\
Llanca & Llanca & Más de 20 casas \\
Qcuita & Kitaplaza & Más de 12 casas \\
Jamallaya & Hamallaya & No quedan casas \\
Suripampa & Suripampa & $1-2$ casas \\
Chiptapampa & Ch'ilkapampa & No quedan casas \\
Ccanaque & Qanaque & No quedan casas \\
Mosocchacra & Mosokhakra & No quedan casas \\
Muraypata & Munaypata & $5-10$ casas \\
Chucpallo & Chokpayo & $3-5$ casas \\
Marquisahui & Markishawi & $6-10$ casas \\
Machingaya & Machingaya & $6-10$ casas \\
Huaynalama & Waynalama & $3-4$ casas \\
Coporama & Wichoqata & No quedan casas \\
Cantupampa & Qantupampa & No quedan casas \\
Umañusu & Umañosu & No quedan casas \\
Ccayra & Qayra & No quedan casas
\end{tabular}

*Treacy, John M.: Las chacras de Coporaque. Andenería y riego en el Valle del Colca, Instituto de Estudios Peruanos, Lima, 1994, pág. 136. 